"An empirical evidence: supplier behavior in the natural materials of buyer supplier relationship"

\begin{tabular}{|c|c|}
\hline AUTHORS & $\begin{array}{l}\text { Sutarmin } \\
\text { Akhmad Darmawan } \\
\text { Siti Nur Azizah (D) https://orcid.org/0000-0001-7710-2695 } \\
\text { Dadang Prasetyo Jatmiko }\end{array}$ \\
\hline ARTICLE INFO & $\begin{array}{l}\text { Sutarmin, Akhmad Darmawan, Siti Nur Azizah and Dadang Prasetyo Jatmiko } \\
\text { (2017). An empirical evidence: supplier behavior in the natural materials of buyer } \\
\text { - supplier relationship. Problems and Perspectives in Management, 15(1-1), 158- } \\
\text { 165. doi:10.21511/ppm.15(1-1).2017.02 }\end{array}$ \\
\hline DOI & http://dx.doi.org/10.21511/ppm.15(1-1).2017.02 \\
\hline RELEASED ON & Wednesday, 10 May 2017 \\
\hline RECEIVED ON & Thursday, 01 September 2016 \\
\hline ACCEPTED ON & Tuesday, 27 December 2016 \\
\hline LICENSE & $\begin{array}{l}(c) \text { EY-NG } \\
\text { This work is licensed under a Creative Commons Attribution-NonCommercial } 4.0 \\
\text { International License }\end{array}$ \\
\hline JOURNAL & "Problems and Perspectives in Management" \\
\hline ISSN PRINT & $1727-7051$ \\
\hline ISSN ONLINE & $1810-5467$ \\
\hline PUBLISHER & LLC "Consulting Publishing Company "Business Perspectives" \\
\hline FOUNDER & LLC "Consulting Publishing Company "Business Perspectives" \\
\hline
\end{tabular}

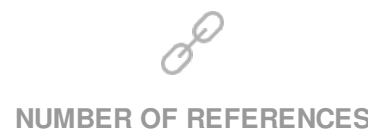

39
NUMBER OF FIGURES

4

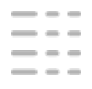

NUMBER OF TABLES

0

(C) The author(s) 2023. This publication is an open access article. 


\title{
An empirical evidence: supplier behavior in the natural materials of buyer - supplier relationship
}

\begin{abstract}
This research is a case study belonging to the historical research. The data were taken from the Department of Natural Product Buying and Financial and Controlling XYZ CORP. XYZ CORP is a manufacturing enterprise and exporter of clove oil and its derivatives to the world with a market share of about $55 \%$ of the world market. This study aims to empirically examine and study the ethical behavior of suppliers in the ever-changing business environment. The analysis tool used is the Mann Whitney test with SPSS 17.0 software. Based on the survey results it was revealed that for natural raw materials, the average purchase price between the rainy season and the dry season does not differ significantly, but the cost of purchase in the dry season, and the rainy season varies significantly. In this study, the price does not affect the acquisition of raw materials purchased from suppliers. The results of this study also obtained empirical evidence that the trading patterns of natural raw materials are strongly influenced by the behavior or ethics of suppliers, in addition to weather factors or uncertain climate.
\end{abstract}

Keywords: natural raw materials, clove oil, suppliers behavior, climate.

JEL Classification: Q31, Q37.

Received on: $1^{\text {st }}$ of September, 2016.

Accepted on: $27^{\text {th }}$ of December, 2016.

\section{Introduction}

Supply chain management falls into the field of management studies that accompany the rapidly growing field of study that has developed other previous managements (Jain et al., 2009). The phenomenon of the rapidly growing supply chain management studies is not only within the scope of academia or research, but the rapid development of supply chain management is also getting into the business application. A supply chain is a dynamic process that includes a continuous flow of materials, funds and information in several functional areas, both within the chain and among members of the chain (Ahi and Serchy, 2013).

Modern business environment becomes almost indefinite, as a result, strategic view of managing the supply chain is very important, especially for complex environments. Business effectiveness shift the focus of corporate competition against companies becoming competitive supply chain against supply chain (Qrunfleh, and Tarafdar, 2013; Li et al., 2006). In a supply chain management, we need a strategic procurement planning. In a strategic procurement planning, supplier selection is one of the most important decisions for a company to buy.

(C) Sutarmin, Akhmad Darmawan, Siti Nur Azizah, Dadang Prasetyo Jatmiko, 2017.

Sutarmin, Ph.D. Candidate from Universitas Jenderal Soedirman and Lecturer at Universitas Peradaban, Indonesia.

Akhmad Darmawan, Lecturer at Faculty of Business and Economic, Universitas Muhammadiyah Purwokerto, Indonesia.

Siti Nur Azizah, Lecturer at STIE Putra Bangsa Kebumen, Indonesia.

Dadang Prasetyo Jatmiko, Auditor at Badan Standardisasi Nasional, Indonesia.

This is an Open Access article, distributed under the terms of the Creative Commons Attribution-NonCommercial 4.0 International license, which permits re-use, distribution, and reproduction, provided the materials aren't used for commercial purposes and the original work is properly cited.
Industry data showed that manufacturing and service supply chain costs as a percentage of sales often have large proportions. For the automotive industry is amounted to $67 \%, 60 \%$ of the food industry, $61 \%$ of wood industry, $61 \%$ of paper industry, $55 \%$ of the oil industry and $52 \%$ of the overall industry average (Heizer and Render, 2006). Because the portion of revenues to the supply chain is highly great, effective purchasing strategy is very important for the company. From the above, it can be seen that the whole industry supply chain costs or raw materials are all above $50 \%$.

In addition to cost and quality, supplier ethics becomes a key factor to be considered after a series of practices of the relationship between buyers and suppliers. The relationship between buyers and suppliers has become the focus and consideration of supply chain management. This supports the idea that trust, commitment, and a long-term orientation are crucial to state effective buyers-suppliers relationships (Griffith et al., 2006; Trautmann et al., 2009). On the other hand, an understanding of the culture can help to increase the confidence and the success of long-term performance in relationship of buyers and suppliers (Ang and Inkpen, 2008). This is in line with the opinion of Stringfellow et al. (2008) and Trent and Monczka (2003), which states that a culture can be strengthening or weakening the relationship.

The empirical findings show that trust and performance in the long-term orientation, managed by the cultural differences, warrant in developing a successful purchasing strategy. Further development states that the effect of trust and performance oriented culture is controlled by the long-term. Buyersupplier relationships are helpful, when the partner in the relationship shows the long-term orientation (Cannon et al., 2010). In addition to providing fi- 
nancial benefits, partnerships with suppliers also provide other benefits such as increasing a harmonious relationship between the company and suppliers, reducing the risk of vertical integration of suppliers, increasing supplier loyalty, reducing suppliers' speculation and improving the quality of the material from the supplier (Sutarmin, 2013). Nevertheless in living relationships, they often occur in unethical behavior by several suppliers.

Unethical behavior is from suppliers, such as the supply of counterfeiters, the distribution of misleading information, and speculation with the detaining of raw materials by not selling to the buyer. This condition will cause a scarcity of raw materials and supply chain system disorder. This kind of incident is often used by certain parties (so-called mafia) to profit from instantaneous (short-term) and less attention to the long-term interests. Unethical behaviors bring social responsibility, which has a negative effect on the company or supply chain (Chen and Baddam, 2015). Awareness and punishment of consumers against unethical practices should be done, although it is not easy. Companies must consider the sustainability of long-term relationships in every strategic decision that has to do with the buyer-supplier relationship. Unethical behavior also often arises uncertain conditions, it often occurs in the supply chain based products and seasonal natures. To study the ethical behavior of suppliers in the ever-changing business environment needs to be tested empirically. There is still little evidence of the behavior of suppliers in the field, utilizing the uncertain situation that could be used as a reference (Sutarmin \& Dadang, 2016).

In studying such situation, companies can choose the contingent policy in determining the purchase price to see the behavior of suppliers in the short term and long term. One of the companies that experienced supply chain issues erratic as natural external factors, such as climate and weather is $\mathrm{XYZ}$ CORP. XYZ CORP in conducting its business relies on the ability to manage their supply chains and relationships with suppliers.

\section{Theoretical framework and hypotheses}

Supply chain management (SCM) is the result of the evolution of the war strategy to the business domain, the name shifted from a variety of terms such as physical distribution management, logistics management, business logistics management and integrated logistics management (Soni and Kodali, 2008). Sustainability is recognized as an important element in the supply chain management (Linton et al., 2007). The integration of sustainable supply chain describes the good performance on the size of the traditional and the expansion of the conceptualization of performance that include social and environmental dimensions (Pagell and $\mathrm{Wu}, 2009$ ).
In the social aspect, ethical suppliers have emerged as an important part of corporate social responsibility in maintaining the organization of alleged unethical behavior and subsequent damage to reputation (Carter and Easton, 2011).

Studies show that although the consumers still buy from unethical suppliers, they punish suppliers by demanding lower prices (Creyer and Ross, 1997). On the other hand, the survey also found that consumers are willing to pay premium prices to the ethical suppliers (De Pelsmacker et al., 2005). In supply chain management, supplier selection is generally considered as one of the most important responsibilities of management (Golmohammadi and Mellat-Parast, 2012). To build a sustainable supply base, the selection of suppliers is an important area of strategic decisions (Goebel et al., 2012). Source strategies in response to the risk of the supplier should consider not only the characteristics and performance, but also the turbulent environment, in which they operate (Trkman and McCormack, 2009). Supplier selection process plays a proactive role in mitigating risk in predicting the consequences and related results that will benefit the company in decision making under uncertainty.

Quantitative models in integrating sustainability issues with traditional supplier selection criteria need to be observed and emphasized (Tang and Zhou, 2012). Most supplier selection decisions use quantitative approaches, such as multi-criteria decision making and analytical hierarchy process (AHP). The focus is on short-term gain trade off between the cost of resources and ethics without considering the cost of switching suppliers (Chan et al., 2008; Dai and Blackhurst, 2012). The literature of risk management has developed a conceptual framework for sustainability risk management (Foerstl et al., 2010). Supplier selection process plays a proactive role in mitigating risk in predicting the consequences and related results that will benefit the company in decision making under uncertainty (Hariyadi, Rahmatika, Sutarmin, \& Dadang, 2016).

Relationships based on long-term orientation allow companies to sacrifice short-term profits in favor of the benefits of both parties in the long term (Narayanan and Raman, 2004). Buyers and suppliers have relationships in problem solving orientation and collaborative bargaining power. Solving this problem results in higher performance and longterm economic relations (Kalwani and Narayandas, 1995). Buyer-supplier relationships include some of the constructions that reflect key aspects of buyersupplier relationships, including the long-term continuity of relationships, commitment and long-term orientation (Liu et al., 2009; Palmatier et al., 2006). While this construction is different in important ways, each emphasizes a closer relationship between the companies to buy and supply company. 
Supply management stated that there are three important aspects that need to be evaluated in supplier performance, namely: (1) the relative price / cost, (2) the performance of the product / service, and (3) the performance of shipping (Prahinski and Benton, 2004). The company will evaluate the primary determinant of profitability, namely the price / performance fees in the form of the purchase price, total cost, and terms of sale. Furthermore, the company will determine whether the company decides to enter into a long term relationship with the supplier or not (Wathne et al., 2001). Heizer and Reinder (2008) stated that the company has to decide on a strategy of supply chain in order to obtain goods and services from outside. Some of the strategies that can be used to establish relationships with suppliers of raw materials and seasonal nature are: (1) Negotiating with many suppliers and pitting one supplier to another supplier. (2) Developing a relationship "partnership" with small long-term suppliers. (3) Vertical integration, where companies can decide to use a reverse vertical integration by actually buying the supplier. (4) A combination of few suppliers of vertical integration, known as keiretsu. In keiretsu, suppliers become part of the corporate entity. (5) Developing a virtual company that uses suppliers as needed.

Specifically, to see if there are differences in the purchase price in the dry season and the rainy, the differences of tally dry season and the rainy season, as well as the effect of the acquisition price, the number of hypotheses are developed as follows:

Hypothesis 1: Is there a significant difference between the average purchase price of raw materials of natural clove oil in the rainy season and dry season.

Hypothesis 2: Is there a significant difference between the acquisition amount of raw material purchases of natural clove oil in the rainy season and dry season.

Hypothesis 3: Does the purchase price affect the amount of natural raw material acquisition.

\section{Research method}

2.1. Sample and procedurs. This research is classified into historical research of a case study. The data used are secondary data, derived from the Department of Natural Product Buying and Financial and Controlling XYZ CORP. XYZ CORP is a manufacturing company that exports its products to all over the world and controls around 55\% of clove oil and its derivatives into the world market. Clove oil and its derivatives are the raw material of flavor and fragrance. The main raw material of XYZ CORP is a natural material that exists in Indonesia. The main raw material of PT XYZ is a natural material that exists in Indonesia. The raw material obtained is, then processed into semi-finished products and exported to the foreign countries in the world. Thus, the nature business of PT XYZ is a B to B (Business to Business). XYZ CORP has implemented ISO 9000, Halal Certification, Kosher Certification, HACCP Certification (ISO 22000) and Organic Certification. XYZ CORP also has to apply the program of integration of information systems SAP (my SAP ERP) with PP (Production Planning), SD (Sales Distribution), MM (Materials Management), QM (Quality Management), FI \& CO (Finance and Controlling ) modules and equipped with $\mathrm{ABAP}$ and BASIC as supporting.

The data used in this study are data on the number of purchase and the purchase price of raw materials, especially clove oil. The research location is in Purwokerto, Cullinan and Jakarta. Determination purposive sample of suppliers based on the criteria (1) is a supplier of clove oil, (2) supplied regularly to XYZ CORP, both bound as a partner, as well as independent suppliers.

2.2. Data analysis. The data analysis of this study uses two different test models of the average and path analysis with SPSS 17.0 software. Different test is carried out on the purchase price, and the average number of acquisition in the dry season and wet season, while the simple path analysis is used to test the effect of price on the acquisition, or purchase amount of clove oil. The preliminary research through normality test showed that the data are abnormal. Since the data are abnormal, different test in this study uses a non-parametric analysis, namely the Mann-Whitney test. While the selected path analysis and regression are not simple, because in this case the researchers only test the significance, not to see his prediction.

2.3. Phenomena analysis. In addition to the hypothetical test, this study will also analyze the phenomena that occur in the case of anomalies laws of supply and unethical supplier of natural raw materials that exist in Indonesia.

\section{Data analysis and discussion}

3.1. Characteristic of company (unit analysis). Each company is required to be able to increase their competitive advantage in the global trading system. Competitive advantage can be manifested through a competitive advantage on the distinction (differentiation), competing on cost, namely through competing on low cost and competitive advantage through the response, the response is flexible, reliable and fast (Porter, 2008). Currently the company is working hard to improve the competitiveness through differentiation, product customization, high quality, cost reduction and fulfillment speed to market, the company provides additional emphasis on the supply chain. Effective supply chain management makes the suppliers "partners" in the company's strategy to meet the ever-changing market. A competitive advantage can rely on long-term strategic relationship that is close to a few suppliers. 
Companies must decide on a strategy of supply chain in order to obtain goods and services from outside. The global crisis hits the world the past few years, resulting in an uncertain business conditions in the next years, not least in Indonesia. Businessmen and importers try to survive by minimizing inventories. Firms in Indonesia that are exportoriented, such as XYZ CORP, are also affected. In this condition, reasonable market conditions occur. In the world of essential oils, many farmers, refiners and collectors rollicking reduce production, but after the crisis began to gradually recover, the importers start buying clove derivatives to fill the void of their inventory and fulfill orders received.

Upon the importer of clove derivatives began to absorb the products, supply chain reaction came too late and entered the rainy season, where the output clove oil is very small. In these conditions, an imbalance between supply and demand occured, where demand expected larger number three times than the existing supply. Although it was under contract agreement, some suppliers still took action or unethical behavior by detaining the goods in order to gain additional profits, when the prices rose.

3.2. Data analysis. Prior to the analysis, whether there is influence of the presence or absence of price on the quantity of goods is obtained by testing the first, namely whether there is a price difference in the dry season and the rainy season (hypothesis 1), and whether there is a difference between the amount of the acquisition of the dry season and the rainy season (hypothesis 2). Based on the analysis of the price, using different test in the dry season and the rainy season with the Mann Whitney asymp values obtained Sig. (2-tailed) 0.716. Because the value is asymp. Sig. (2-tailed) $0.716>0.05$, this shows that the hypothesis $\mathrm{H}_{\mathrm{o}}$ is accepted or, in other words the price for the dry season and the rainy sea- son is not significantly different. Mann Whitney analysis is performed because preliminary analysis shows that the data does not qualify normality.

Based on the analysis of the quantity using different test in the dry season and the rainy season with Mann Whitney (Hypothesis 2), the value obtained is asymp. Sig. (2-tailed) 0.000 . Because the value is asymp. Sig. (2-tailed) $0.000>0.05$, this shows that hypothesis $\mathrm{H}_{\mathrm{o}}$ is rejected or, in other words, the price for the dry season and the rainy season is significantly different. Such as mobile in terms of normality test of price, the quantity of Mann Whitney analysis is performed, because preliminary analysis indicates that the data are not normal.

Based on the analysis of pathways influence, the price of the purchase amount of clove oil standardized coefficient value (beta) is 0.106 with sig. 0.459 . Because Sig. value $0.459>0.05$, this shows that the hypothesis $\mathrm{H}_{\mathrm{o}}$ is accepted, or in other words the price does not significantly affect the amount of acquisition purchase. This contrasts with the laws of supply conditions, stating that the price is directly proportional to the number of deals. This phenomenon occurs because the natural material is not merely to follow the law of supply, but more influenced by the harvest season (seasonal), as well as the behavior of suppliers.

3.3. Phenomena analysis. Although the prices are very high, but if you are not in the season, then, the amount of clove oil obtained will still be inconsiderable. These conditions will be very vulnerable to speculative activities of the suppliers. The speculative activity itself is unethical behavior from suppliers that are already partnering with the buyer. Figure charts of the average price and the number of acquisition can be seen in Figure 1 .

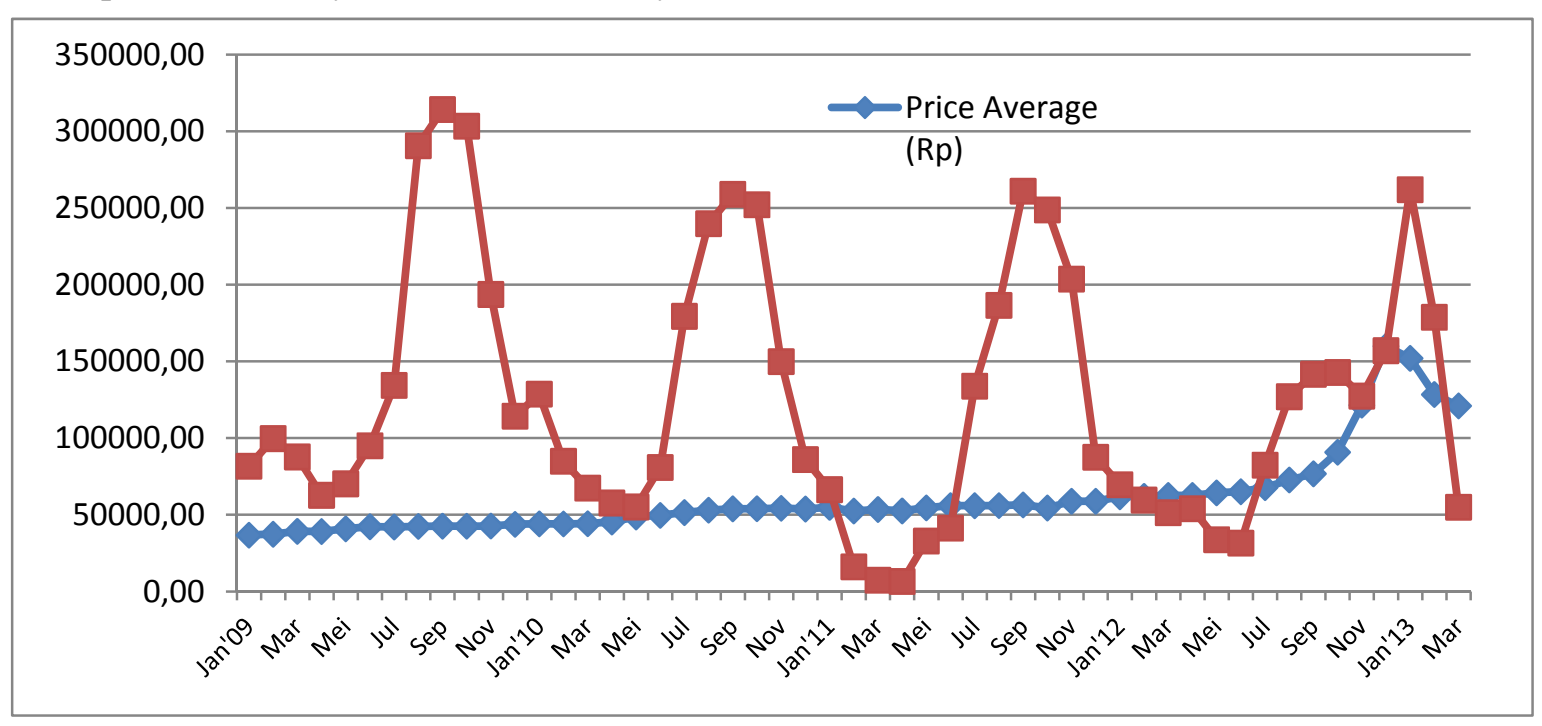

Source: Department of Natural Product Buying XYZ CORP.

Fig. 1. The price and the number of acquisition 
In Figure 1, it can be explained that periodically highest achievement starts in July and peaks in September and the lowest acquisition acquired is in April each year. However, the phenomenon occurred since 2012, where in September at that year did not obtain the maximum number of clove oil, but only about half of the same month in previous years. The highest peak was precisely obtained in January next year.

This is a result to natural conditions in Indonesia, who are experiencing erratic changes in weather (climate change). In addition to weather phenomena, such business is also affected by factors (1) market Nervousness by exporters or buyers for their deficiency (shortage) of raw materials, (2) the existence of unethical behavior from suppliers that speculate to hold material to obtain the highest possible price. (3) the policy of the exporters, who continue to raise the purchase price in order to obtain supplies as much as possible.

Policy strategies continuously raise the purchase price on July 2012, this would make the suppliers increasingly speculated to resist to obtain the highest price. Suppliers' behavior that secures the raw material is certainly disturbing the short-term and long-term relationship with the buyer. Unethical behavior of suppliers became empirical evidence after the prices were lowered in the end of 2012, it turned raw materials began to be sold by the supplier, so that the acquisition was abundant in January and February 2013, and has never occurred in previous years, as can be seen in Figure 1, 2 and 3.

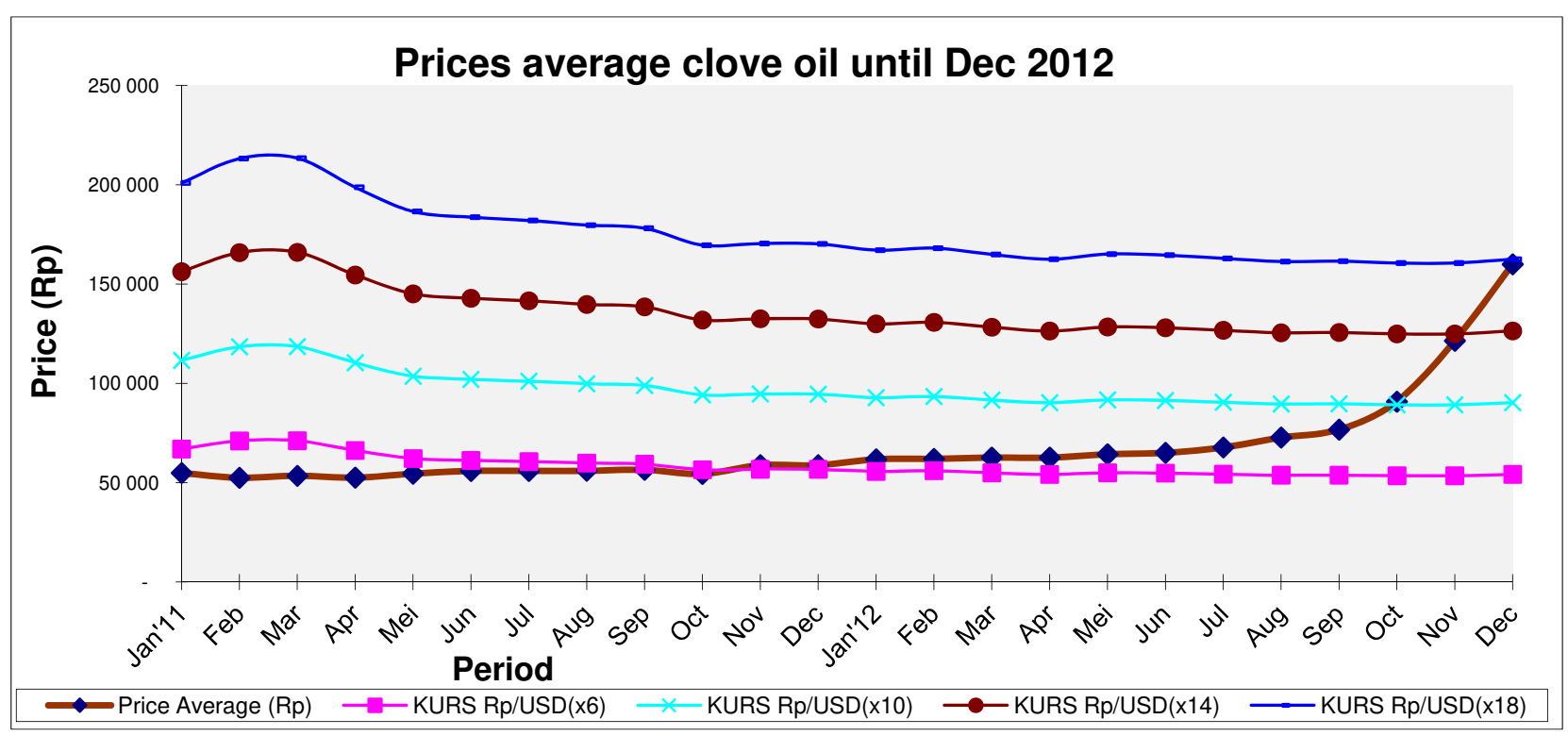

Fig. 2. Average price of purchase until December 2012

Source: purchasing and finance statements XYZ CORP (processed).

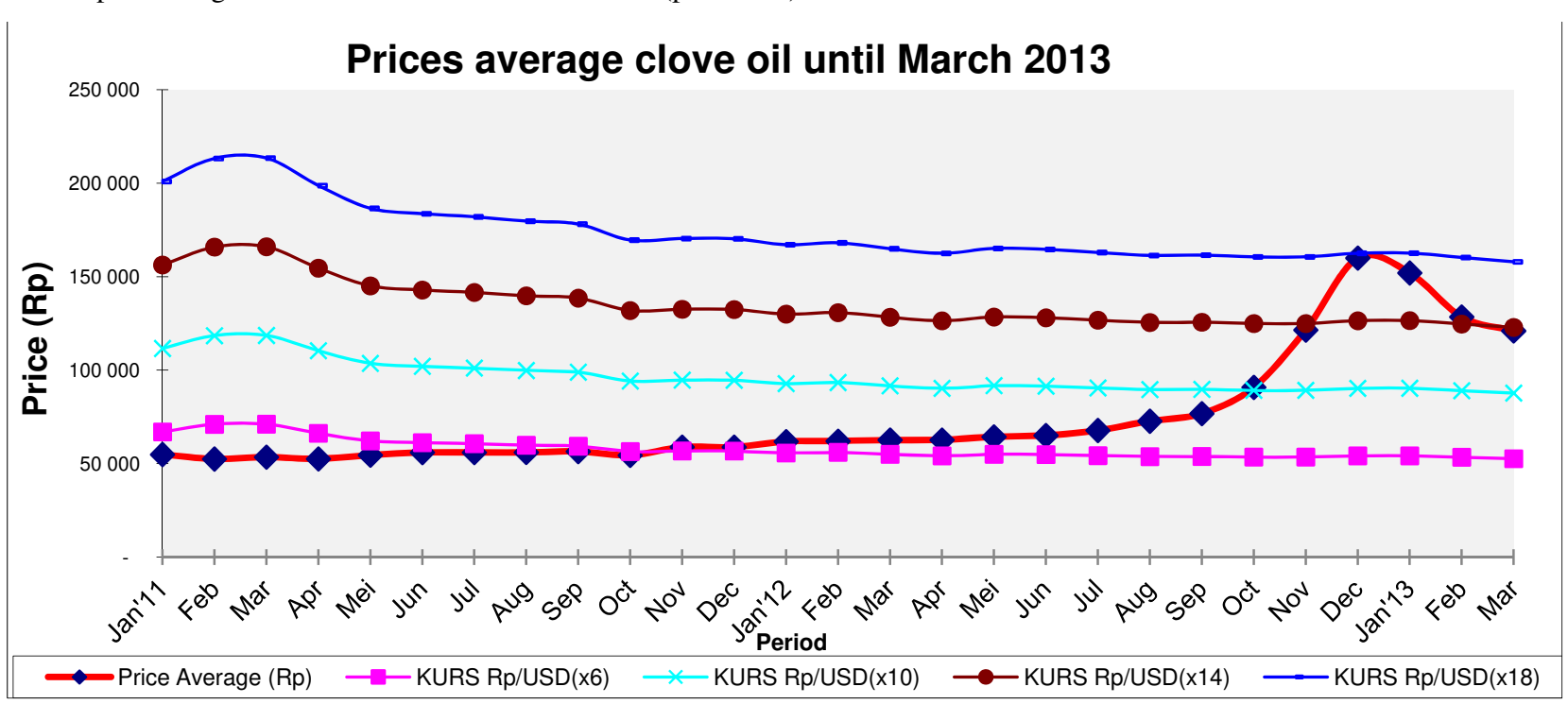

Fig. 3. Purchase price until March 2013 (after price lowered)

Source: purchasing and financial statements XYZ CORP (processed) 


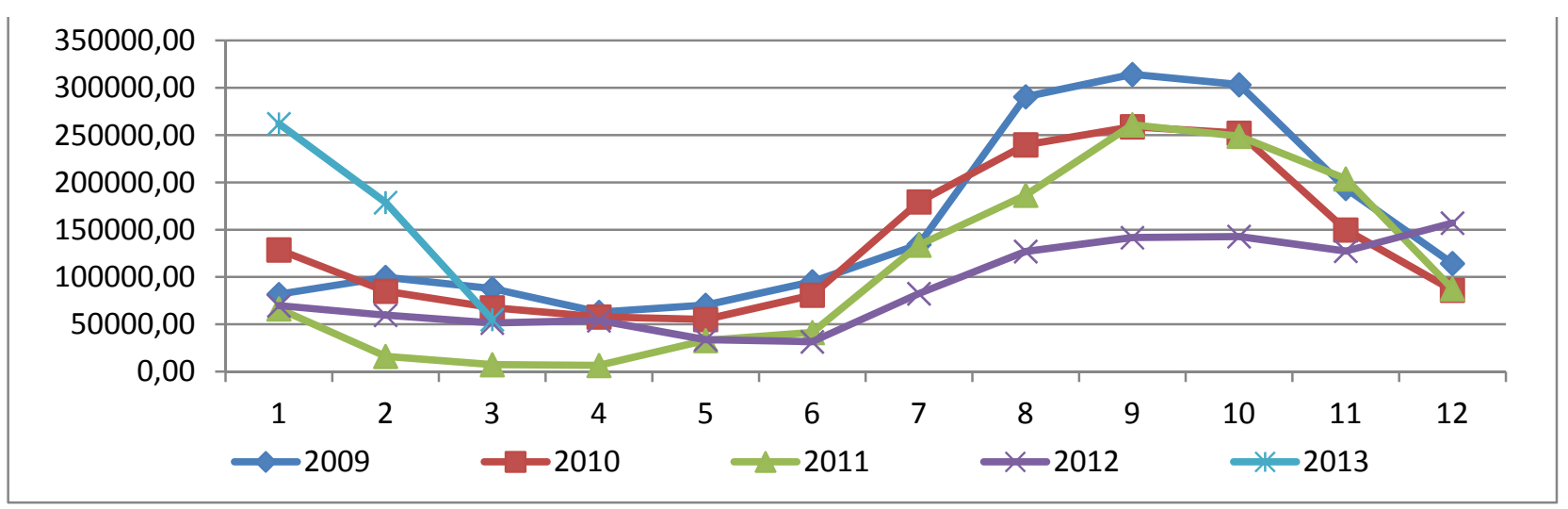

Fig. 4. Acquisition patterns of clove oil until March 2013

Source: Report of the purchase amount XYZ CORP (processed)

This case study can demonstrate that the behavior of suppliers as speculators is instrumental in clove oil trading system in Indonesia.

\section{Conclusion, implication, suggestions, and limitations}

Based on these results, it can be concluded that for the natural raw materials, the average purchase price between the rainy season and the dry season does not differ significantly, but the cost of purchase in the dry season and the rainy season varies significantly. The results also show that the purchase price does not affect the acquisition of clove oil purchases. Seasonal conditions can actually be predicted by operators, which high gains to be obtained in the dry season, but to factor the unethical behavior of suppliers is very difficult to predict. Uncertain condition is often exploited by suppliers of natural raw materials, in this case, clove oil, by taking advantage of the shortage of the unethical behavior, speculating to hold raw materials and not to sell until the prices soar. Action or unethical behavior is actually going to disrupt the buyer-supplier relationships both in a short term and long term.

It is recommended that the manufacturers or exporters perform better forecasting, accompanied by additional information about climate and weather prediction. In addition, the company must add a greater buffer stock of inventory, which is sufficient for the manufacturing process and exports up to season acquisition in the coming year, although it would be a financial burden. Companies are also expected to share information and purchase contracts to monthly annual with suppliers, so that the two sides will mutually benefit.

This study has limitations, especially the unit of analysis is only one manufacturing exporter of natural raw materials. Because of the secret nature of a family company that is not open yet (go public), the company's original name is obscured. Although the actual transaction prices fairly represent all transactions in Indonesia, the samples taken are only suppliers, who sell to XYZ CORP.

\section{Acknowledgements}

We would like to acknowledge the support of the Doctoral Program of Management Sciences, University of Jenderal Soedirman, who has facilitated everything for the publication of this research article.

Note. For reasons of confidentiality, the name of the manufacturer cannot be disclosed. XYZ CORP is a pseudonym.

\section{References}

1. Ahi, P., Serchy, C. (2013). A comparative literature analysis of definitions for green and sustainable supply chain management. Journal of Cleaner Production, 52, 329-341.

2. Ang, S., Inkpen, A. C. (2008). Cultural intelligence and offshore outsourcing success: a framework of firm-level intercultural capability, Decision Sciences, 39 (3), 337-358.

3. Cannon, Joseph P., Patricia M. Doney, Michael R. Mullen and Kenneth J. Petersen (2010). Building Long-Term Orientation in Buyer-Supplier Relationships: The Moderating Role of Culture. Journal of Operations Management, 28 (6), 506-521. Available at: http://dx.doi.org/10.1016/j.jom.2010.02.002.

4. Carter, C.R., Easton, P.L. (2011). Sustainable supply chain management: evolution and future directions. Internatioanl Journal. Physical Distribution and Logistic Managemanet, 41 (1), 46-62.

5. Chen, Jen-Yi and Swathi R. Baddam (2015). The Effect of Unethical Behavior and Learning on Strategic Supplier Selection. International Journal of Production Economics, 167, 74-87.

6. Creyer, E.H., Ross, W.T. (1997). The influence of firm behavior on purchase intention: do consumers really care about business ethics? Journal Consumption Marketing, 14 (6), 421-432.

7. Chen, Jen-Yi and Swathi R. Baddam (2015). The Effect of Unethical Behavior and Learning on Strategic Supplier 
Selection. International Journal of Production Economics, 167, 74-87. Available at: http://www.sciencedirect.com/science/article/pii/S0925527315001346.

8. Chan, F.T.S., Kumar, N., Tiwari, M.K., Lau, H.C.W., Choy, K.L. (2008). Global supplier selection: a fuzzy-AHP approach. International Journal of Production Research, 46 (14), 3825-3857.

9. Dai, J., Blackhurst, J. (2012). A four phase AHP-QFD approach for supplier assessment: a sustainability perspective. International Journal of Production Research, 50 (19), 5474-5490.

10. De Pelsmacker, P., Driesen, L., Rayp, G. (2005). Do consumers care about ethics? Willingness to pay for fair-trade coffee. Journal Consumption Aff., 39 (2), 363-385.

11. Elkington. (1997). Cannibals with Forks: the Triple Bottom line of $21^{\text {st }}$ Century Business. Capstone, Oxford.

12. Foerstl, K., Reuter, C., Hartmann, E., Blome, C. (2010). Managing supplier sustainability risks in a dynamically changing environment - sustainable supplier management in the chemical industry. Journal of Purchasing \& Supply Management, 16 (2), 118-130.

13. Ganesan, S. (1994). Determinants of long-term orientation in buyer-seller relationships. Journal of Marketing 58, (2), 1-19.

14. Goebel, P., Reuter, C., Pibernik, R., Sichtmann, C. (2012). The influence of ethical culture on supplier selection in the context of sustainable sourcing. International Journal Production Economic, 140 (1), 7-17.

15. Golmohammadi, D., Mellat-Parast, M. (2012). Developing a grey-based decision-making model for supplier selection. International Journal Production Economic, 137 (2), 191-200.

16. Griffith, D.A., Harvey, M.G., Lusch, R.F., (2006). Social exchange in supply chain relationships: the resulting benefits of procedural and distributive justice. Journal of Operations Management, 24 (2), 85-98.

17. Finance \& Controlling. (2013). Financial Report, XYZ CORP, Jakarta.

18. Hariyadi, Rahmatika, Sutarmin, S. \& Dadang. (2016). The Impact of Desain Component_International Business management. International Business Management, 10 (20), pp. 4907-4916. doi:10.3923/ibm.2016.4907.4916.

19. Heizer, Jay and Render, Barry. (2008). Operation Management. $9^{\text {th }}$ edition. Pearson education: New Jersey.

20. Jain, V., Wadhwa, S., Deshmukh, S.G. (2009). Select supplier-related issues in modeling a dynamic supply chain: potential, challenges and direction for future research. International Journal of Production Research, 47 (11), 3013-3039.

21. Kalwani, M.U., Narayandas, N. (1995). Long-term manufacturer-supplier relationships: do they pay off for supplier firms? Journal of Marketing, 59 (1), 1.

22. Linton, J., Klassen, R., Jayaraman, V. (2007). Sustainable supply chains: an introduction. Journal of Operational Management, 25 (6), 1075-1082.

23. Liu, Y., Luo, Y., Liu, T. (2009). Governing buyer-supplier relationships through transactional and relational mechanisms: evidence from China. Journal of Operations Management, 27 (4), 294-309.

24. Narayanan, V.G., Raman, A. (2004). Aligning incentives in supply chains. Harvard Business Review, 82 (11), 94-102.

25. Palmatier, R.W., Dant, R.P., Grewal, D., Evans, K.R. (2006). Factors influencing the effectiveness of relationship marketing: a meta-analysis. Journal of Marketing, 70 (4), 136-153.

26. Porter, M.E. (1996). Wha tis Strategy? Harvard Business Review, November - December, 74 (Issue 6), 61-78.

27. Qrunfleh, S., Tarafdar, M. (2013). Lean and agile supply chain strategies and supply chain responsiveness: the role of strategic supplier partnership and postponement, Supply Chain Management: an International Journal, 18 (6) 571-582.

28. Pagell, M., Wu, Z. (2009). Building a more complete theory of sustainable supply chain management using case studies of 10 exemplars. Journal of Supply Chain Management, 45 (2), 37-56

29. Prahinski, C., Benton, W.C. (2004). Supplier evaluations: communication strategies to improve supplier performance. Journal of Operations Management, 22, 39.

30. Soni, G., Kodali, R. (2008) Evolution of Supply Chain Management: Developments in Academia and Industry, The Icfai University Journal of Supply Chain Management, 5 (4).

31. Hariyadi, Rahmatika, Sutarmin, S. \& Dadang. (2016). The Impact of Desain Component_International Business management. International Business Management, 10 (20), pp. 4907-4916. doi:10.3923/ibm.2016.4907.4916.

32. Sutarmin, S. \& Dadang. (2016). Value chain analysis to improve corporate performance: a case study of essential oil export company in Indonesia. Investment Management and Financial Innovations, 13 (3). doi: http://dx.doi.org/10.21511/imfi.13(3-1).2016.04.

33. Stringfellow, A., Teagarden, M.B., Nie, W. (2008). Invisible costs in offshoring services work. Journal of Operations Management, 26 (2), 164-179.

34. Tan, K.H., Lyman, S.B. and Wisner, J.D. (2002). Supply chain management: a strategic perspective, International Journal of Operations \& Production Management, 22 (6), 614-631.

35. Thomas, D.J., Griffin, P.M. (1996). Coordinated Supply Chain. European Journal of Operational Research, 94 (1), 1-15.

36. Trautmann, G., Turkulainen, V., Hartmann, E., Bals, L. (2009). Integration in the global sourcing organization: an information processing perspective. Journal of Supply Chain Management: A Global Review of Purchasing \& Supply, 45 (2), 57-74. 
37. Trent, R.J., Monczka, R.M. (2003). International purchasing and global sourcing - what are the differences? Journal of Supply Chain Management: A Global Review of Purchasing \& Supply, 39 (4), 26-37.

38. Trkman, P., McCormack, K. (2009). Supply chain risk in turbulent environments - a conceptual model for managing supply chain network risk. International Journal Production Economic, 119 (2), 247-258.

39. Wathne, K.H., Biong, H., Heide, J.B. (2001). Choice of supplier in embedded markets: relationship and marketing program effects. Journal of Marketing, 65 (2), 54-66. 